\title{
HUBUNGAN ANTARA EKONOMI KERAKYATAN DENGAN PANCASILA SILA KE-4
}

\author{
1Arif Ramadhan, 2Awaludin Sinur Kholis, 3Anita Trisiana \\ "Mahasiswa Pertanian Universitas Slamet Riyadi Surakarta \\ "Mahasiswa Pertanian Universitas Slamet Riyadi Surakarta \\ "Dosen PPKn Universitas Slamet Riyadi Surakarta
}

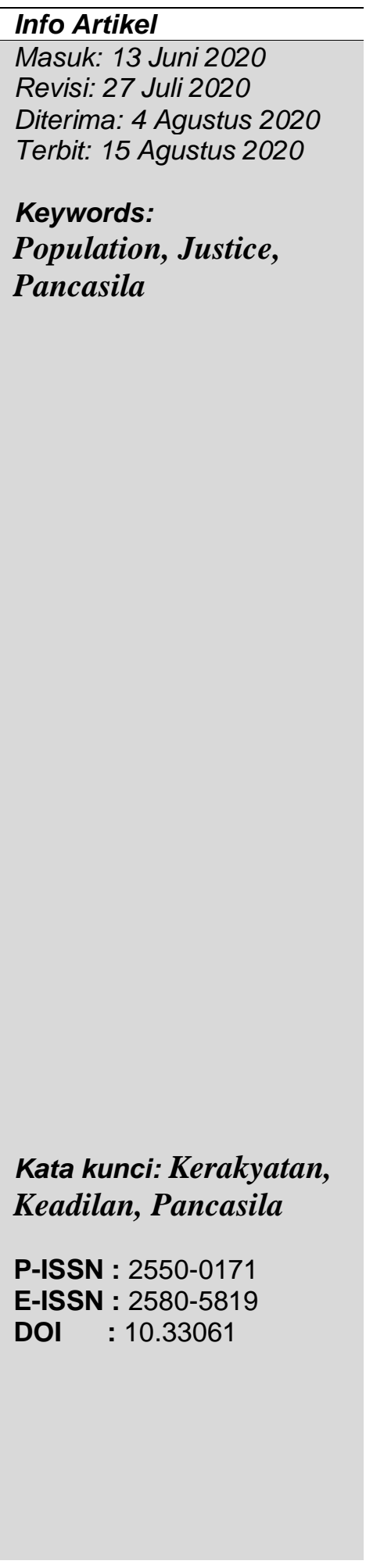

\section{Abstract}

Turn of thought and is spend some time talking about the economic system force of the people $\mathrm{s}$ in disorder no matter how directly associated with muamalat ran into financial difficulties the most number of the 4th SILA. Have gone before you that "force of the people $s$ that is presided over by skillful and godly wisdom discretion in representative after being suspended from the children of a deceased". That means even all the house of representatives had to be involved in determining economic policy must be in accordance with mutual agreement or consensus. It is meant to reach for a ideals of society fair, honest, responsible, and prosperous. So that economic strength of the latest in a it is becoming concerned about more influenced a little bit about what an economic system that in practice the by to the state has solid . Indonesia when now applied economic system strategic i.e. the system economic kerakyatan, where in carrying out economic system controlled by the people. But in carrying out the economic system society-based have to need the considerations that were ripe, such as indonesia in determining sisem economic society-based. If you look at history, at the beginning of a developing country, especially Indonesia previously embraced the theory of growth in its economic system. Indonesia now does not adhere to the theory of growth because this principle actually experiences a failure. Therefore, Indonesia currently holds fast to the principle of populist economy.

\section{Abstrak}

Pemikiran dan pembahasan tentang sistem ekonomi kerakyatan secara tidak langsung berkaitan dengan Pancasila yaitu SILA KE-4. Yang berbunyi "Kerakyatan yang dipimpin oleh hikmat kebijaksanaan dalam permusyawaratan perwakilan". Yang mempunyai arti yaitu seluruh wakil rakyat harus ikut serta dalam menentukan kebijakan ekonomi harus sesuai dengan kesepakatan bersama atau mufakat. Hal ini bertujuan untuk menggapai suatu cita-cita masyarakat yang adil, jujur, bertanggung jawab, dan sejahtera. Sehingga kekuatan ekonomi disuatu negara itu lebih dipengaruhi dengan bagaimana sistem ekonomi yang di terapkan oleh 
negara tersebut. Indonesia saat ini menerapkan sistem ekonomi yang strategis yaitu sistem ekonomi kerakyatan, dimana dal am melaksanakan sistem ekonomi itu dikendalikan oleh rakyat. Tetapi dalam melaksanakan sistem ekonomi kerakyatan harus membutuhkan pertimbangan yang matang, seperi indonesia dalam menentukan sisem ekonomi kerakyatan. Jika dilhat dalam sejarah, pada awal mulanya suatu negara berkembang,khususnya indonesia sebelumnya menganut teori pertumbuhan dalam sistem ekonominya. Indonesia sekarang tidak menganut teori pertumbuhan karena prinsip tersebut malah mengalami suatu kegagalan. Oleh karena itu, Indonesia saat ini memegang teguh pada asas ekonomi kerakyatan.

\section{PENDAHULUAN}

Pada tahap-tahap permulaan perencanaan pada ummnya berkenan dengan bidang ekonomi, oleh karena itu kecenderungan, utamanya adalah ilmu perencanaan yang berkembang paling maju yaitu perencanaan pembangunan di bidang ekonomi. Dilihat dari segi pembangunan ilmu ekonomi dapat dianggap sebagai salah satu pemenuhan kebutuhankebutuhan ekonomi dengan sumber- sumber yang bersifat langka. Pertumbuhan pembangunan ekonomi ini mengemukakan dalil bahwa pertumbuhan perkembangan ekonomi harus diatur oleh pemerintah, karena ini adalah tugas dari pemerintah. Gagasangagasan pertumbuhan perkemangan ekonomi harus ada usaha campur tangan pemerintah untuk memperbaiki ekonomi pembangunan dan pertumbuhannya. Perencanan ekonomi kerakyatan sangat berkaitan erat dengan sila yang terkandung dalam pancasila.

Ilmu-ilmu perkembangan ekonomi mengorientasikan untuk mendukung perumusan kebijakan pembangunan ekonomi kerakyatan banyak dikalangan masyarakat berpendapat bahwa, disini masih terdapat kelemahan-kelemahan. Bagaimanapun juga bahwa mengenai yang terakhir ini terus ditumbuhkan. Perkembangan terakhir misalnya mengenai pengembangan ekonomi kerakyatan dalam pertumbuhan masyarakat dan indikator ekonomi kerakyatan merupakan petunjuk pengelihatan yang lebih detail daripada ilmu perencanaan. Susuai dengan kecenderungan dahulu, perencanaan ekonomi kerakyatan berkembang menjadi perencanaan pembangunan yang harus diakui sebenarnya dalam pembentukan analisa yang berkembang dan utamanya dalam perencanaan ekonomi pembangunan 
kerakyatan. Kecenderungan-kecenderungan ini dapat diperkuat pula dengan adanya pengalaman-pengalaman perencanaan pembangunan yang dimulai di berbagai negara. Indonesia merupakan salah negara yang menganut sistem perencanaan pembangunan ekonomi kerakyatan, sistem eknomi ini sangat mendukung sebuah kemajuan dan pekembangan di negara. Salah satu alasan indonesia menganut sistem ini, karena pada dasarnya indonesia merupakan negara demokrasi, dimana segala kegiatan selalu di kuasi oleh rakyat.Tugas pemerintah disini hanya untuk menampung semua pendapat masyarakat dan memberikan sebuah solusi. Ekononomi kerakyatan ini berasal dari tingkat keluarga, masyarakat, sekolah dan kampus.

\section{METODE PENELITIAN}

Dalam pembahasan ini, pancasila akan berperan sebagai nilai lain yang akan dihubungkan kedalam konsep ekonomi kemasyarakatan. Dan dalam penetitian ini penulis menggunakan tipe penelitian deskriptif kualitatif, khususnya pada sistem etnografi. Menurut Sugiyono (2013:2), "Metode penelitian pada dasarnya merupakan cara ilmiah untuk mendapatkan data dengan tujuan dan kegunaan tertentu".

Menurut Darmadi (2013:153), "Metode penelitian adalah suatu cara ilmiah untuk mendapatkan data dengan tujuan kegunaan tertentu”. Sedangkan menurut Creswell (2010:4), "Metode - metode untuk mengeksplorasi dan memahami makna yang oleh sejumlah individu atau kelompok orang dianggap berasal dari masalah sosil atau kemanusian”.

Arifin (2011) "Observasi adalah suatu proses pengamatan dan pencataan secara sistematis, logis, objektif dan rasional mengenai berbagai fenomena, baik dalam situasi yang sebenarnya maupun dalam situasi buatan untuk mencapai tujuan tertentu”. Menurut Jogiyanto(2008) “Observasi adalah teknik atau pendekatan untuk mendapatkan data primer dengan cara mengamati langsung". Tujuan dari kedua para ahli diatas yakni agar penulis dapat memberikan informasi yang lebih akurat dan rinci, dan nantinya dapat menyakinkan para pembaca. Serta penulis juga dapat merasakan apa yang dilakukan di penelitiannya atau dengan kata lain penulis dapat mendeskripsikan semua yang berkaitan dengan objek atau sasaran yang ditelitinya.

\section{Teknis Analisis Data}


Sugiyono (2014:244), "Proses menyusun secara sistematis data yang di peroleh dari hail wawancara,catatan lapangan dan dokumentasi,dengan cara mengorganisasikan data kedalam katagori,menjabarkan ke dalam unit-unit, melakukan sistensa, menyusun ke dalam pola, memilih mana yang penting dan yag akan di pelajari, dan membuat kesimpulan sehingga mudah dipahami oleh diri sendiri maupun orang lain”.

\section{PEMBAHASAN}

\section{Pengertian Ekonomi Kerakyatan}

Didalam menjalankan suatu kehidupan berbangsa dan bernegara baik secara internasioal telah diketahui beberapa sistem ekonomi yang menjadi salah satu pedoman untuk melaksanakan sebuah perekonomian.

Sistem ekonomi kerakyatan merupakan suatu sistem yang bergerak dengan kekuatan dari rakyat. Ekonomi kerakyatan sangat memberikan kemudahan bagi masyarkat, karena ekonomi kerakyatan sangat mendukung kemajuan perekonomian di negara Indonesia. Indoneisa sebagai negara yang berpedoman pada ideologi pancasila telah menerapkan taraf ekonomi yang sesuai dengan ajaran pancasila.

Sistem ekonomi kerakyatan yang ajarkan oleh pancasila adalah sistem ekonomi kerakyatan, dijelaskan dalam sistem ekonomi kapitalisme yang mendeskripsikan tentang pemerasan terhadap masyarakat bawah dan bersifat egois atau dengan kata lain individualisme. Sedangkan sistem ekonomi pembangunan kerakyatan tidak mengajarkan penindasan terhadap masyarakat bawah, semua sistem ekonomi kerakyatan sudah dikoordinasikan secara jelas, dan sudah dipastikan hal ini memiliki sifat yang musyawarah dan mufakat yang tentunya sesuai dengan ajaran-ajaran pancasila. Pancasila sebagai cita-cita dan UUD 1945 sebagai cara untuk mengapai cita-cita bersama. Oleh karena itu pancasila sebagai acuan untuk menentukan suatu permasalahan.

\section{Sistem kerakyatan memiliki ciri-ciri yaitu}

a. Berporos pada kinerja pacar yang berkeadilan dengan konsep persaingan yang baik.

b. Mengendali pertumbuhan ekonomi, nilai keadilan, kepentingan masyarakat, dan tujuan hidup. 
c. Untuk mewujudkan perkembangan berwawasan lingkungan dan berkepanjangan.

d. Menjamin harapan yang sama dalam berkerja dan berwirausaha.

\section{Tujuan ekonomi kerakyatan}

Dari dua penjelasan yang di tulis yaitu penjelasan tentang pengertian ekonomi kerakyatan dan ciri- ciri. Dapat kita temukan tujuan dari ekonomi kerakyatan tersebut, yaitu:

a. Untuk mengembangkan dari penyorotan pendapatan di setiap individu atau kelompok masyarakat.

b. Untuk meningkatkan kemudahan dari perekonomian nasional.

c. Suapaya dapat memajukan pertumbuhan ekonomi yang berkelanjutan

\section{Penggunaan nilai-nilai pancasila dalam ekonomi kerakyatan}

\section{a. Nilai ketuhanan yang maha Esa, dalam sistem ekonomi kerakyatan}

Asas dari niai pancasila yang pertama adalah sebuah sikap yang mendasari sebuah perilaku dan mora dari dalam diri manusia. Walaupun ketersediaan mengendalikan dirinya untuk singkat menghormati dan tenggang rasa. Dengan maksud diharapkan terdapat sebuah sikap pantang menyerah dalam membangun sistem pembentukan ekonomi kerakyatan tidak dengan mengabaikan kesenjangan antara satu dengan yang lain. Demi tujuan menciptkan suasana gotong royong serta bertakwa kepada Tuhan YME.

\section{b. Nilai kemanusiaan yang adil dan beradab, dalam sistem ekonomi kerakyatan}

Semangat kerakyatan, cinta-mencintai, kepada seluruh anggota masyarakat akan menjadi semangat sosial menuju kemerataan sosial. Semangat solidaritas akan menebal dalam keadaan susah maupun senang dan sebaliknya kecenderungan menipis dalam serba kemakmuran.

\section{c. Persatuan indonesia, dalam sistem ekonomi kerakyatan}

Semangat cinta tanah air dibidang ekonomi kerakyatan selalu menjiwai bangsa indonesia. Semangat ini dapat ditingkatkan dengan cara seluruh kegiatan perekonomian harus di kerjakan oleh rakyat itu sendiri denga kata lain mengunakan produk dalam negeri. 
d. Kerakyatan yang dipimpin oleh hikmah kebijaksanaan dalam permusyawaratan perwakilan, di sistem ekonomi kerakyatan

Dalam melakukan sistem ekonomi kerakyatan harus sesuai dengan asas kekeluargaan dan kedisiplinan nasional yang harus atau wajib dipatuhi semua masyarakat indonesia. Itu merupakan etika yang harus dimiliki oleh tiap-tiap individu. Dan diartikan sebagai semua keputusan yang di terapkan untuk melaksanakan perekonomian di suatu negara haruslah secara berama dengan selalu mengedepankan kepentingan rakyat dan dilakukan secara jujur sadar serta tanggung jawab.

\section{e. Keadilan sosial bagi seluruh rakyat Indonesia, dalam ekonomi kerakyatan}

Keadilan sosial adalah permasalah yang telah lama menjadi pemikiran bersama khususnya bagi pengamat pancasila. Negara indonesia menerapkan suatu keadilan sosial bagi semua warga negaranya dengan tujuan akhir yang mengambarkan sebagai masyarakat yang adil dan sejahtera. Hal ini merupakan semua warga negara yang menetap dalam suatu wilayah harus mendapatkan perlakuan yang adil baik dalam bidang hukum, politik, ekonomi, maupun budaya.

\section{KESIMPULAN}

\section{KESIMPULAN}

Berdasarkan pembahasann diatas dapat ditegaskan bahwa sistem ekonomi kerakyatan dalam berpancasila sangatlah penting bagi pertumbuhan perekonomian di negara Indonesia .ekonomi kerakyatan merupakan suatu sistem yang bergerak dengan kekuatan dari rakyat. Oleh karena itu ekonomi kerakyatan sangat berhubungan erat degan pancasila terutama pada alinea ke-4. Ekonomi kerakyatan menjadi unjung tombak perekonomian di indonesia, karena meliputi usaha-usaha yang dapat di jangkau oleh masyarakat menengah dan dapat mengurangi tingkat pengangguran di indonesia.

\section{SARAN}

Dengan menulis penelitian ini, penulis mengharapan kepada pembaca agar dapat menjadi acuan dalam mengatasi kegiatan perekonomian di indonesia yang sebagian besar 
masih hidup dalam serba kekurangan atau kemiskinan. Jika ingin menjalankan suatu sistem ekonomi kerakyatan ini agar berjalan dengan baik, harus ada kesadaran diri dari para pejabat, untuk tidak melakukan tindakan yang tidak terpuji.

\section{Bagi pemerintah}

Pemerintah diharapkan dapat menjalankan kegiatan ekonomi kerakyatan dengan baik, karena sebagian besar warga bangsa indonesia bergerak di bidang ekonomi mikro dan kelamahan yang ada dalam sistem ini harus bisa di tangani oleh pemerintah, terutama masalah korupsi.

\section{Bagi Masyarakat}

Masyarakat sekiranya mampu berkontribusi dalam segala program yang dikerjakan oleh pemerintah dan dihrapkan masyarakat bisa membuat sebuah inovasi yang kreatif dalam kegiatan perekonomian sehingga dapat mengurangi angka pengangguran di Indonesia.

\section{DAFTAR PUSTAKA}

Arifin, Zainal. 2011. Evaluasi Pembelajaran Prinsip, Teknik, Prosedur, Bandung: PT Remaja Rosdakarya.

Ayu, Felisia Mega Sri, dan Trisiana, Anita, 2017. Penguatan Pancasila Dalam Perbuatan (Alternatif Tindakan Kuratif Di Era Globalisasi. Global Citizen, Vol. 4 No. 2, Pp. 14-19.

Jaelani, Aan. 2016. Pancasila Economic and the Challenges of Globalization and Free Market In Indonesia, Cirebon.IAIN Syekh Nurjati.

Jogiyanto, 20018, Metode Penelitian Sistem Informasi, Yogyakarta: Andi Offset.

Eddya eko, S. 2014. Penerapan Nilai-nilai Pancasila Dalam Kebijakan Ekonomi di Kabupaten Tegal, Tegal.

Djojohadikusumo, Sumitro. 1979. Indonesia Dalam Perkembangan Dunia Kini Dan Masa datang, Jakarta: PT Pembangunan.

Firdaus, Arrayyan. 2017. Pancasila Enerprise Theory and Pancasila Bottom: Suatu Kajian Mengakuisisi Akuntansi Ke-Indonesia-an dari Jeratan Kapitalisme,Jurnal Ilmiah 
Moh. Hatta, 1996. Peranan pemuda menuju Indonesia merdeka Adil dan Makmur, Jakarta: Tinta Mas.

Mubyarto. 2003. Ekonomi Pancasila, Yogyakarta. Bappenas.

Rahardjo M. Dawam. 1967. Menuju Sistem Perekonomian Indonesia, Jakarta. LSAF Jakarta. Sugiyono, 2013. Metod penelitian Kuantitatif. Bandung: Alfabeta.

Tjokroamidjojo Bintoro. 1976. Perencanaan Pembangunan, Jakarta: PT Inti Idayu Press.

Todaro Michael. 1983. Pembangunan Ekonomi didunia ke Tiga, Jakarta Timur: Balai Aksara. 